\title{
Pedagogi di Era Digital dalam Konteks Pandemi Covid-19
}

\section{Pedagogy in the Digital Age in the Context of the Covid-19 Pandemic}

\author{
Martin Elvis ${ }^{1)^{*}}$ \\ ${ }^{1)}$ Sekolah Tinggi Teologi Cipanas \\ *Penulis Korespondensi: martin.elvis@sttcipanas.ac.id
}

Received: 2005 2020/Revised: 0906 2020/ Accepted: 10062020

\begin{abstract}
Abstrak
Masalah pandemi COVID-19 membuat proses belajar dan mengajar tidak dapat dilaksanakan dengan tatap muka lagi, maka dialihkan menjadi proses belajar dan mengajar jarak jauh atau online. Hal ini mengakibatkan pedagogi juga mengalami perubahan, termasuk para pendidik dalam melaksanakan proses belajar dan mengajar. Tujuan penelitian ini adalah untuk mendapatkan konsep pedagogi yang tepat agar dapat diimplementasikan pada masa pandemi Covid-19. Menggunakan metodologi penelitian kualitatif; melakukan analisis kualitatif dengan memilih dan meneliti tujuh konsep perkembangan pedagogi terbaru di era digital dan hasil penelitian dari jurnaljurnal dalam lima tahun terakhir. Dari hasil penelitian dapat disimpulkan perlunya diterapkannya konsep baru yang relevan Pedagogi di era digital dalam konteks pandemi Covid-19 dengan mengambil nilai-nilai penting dari ketujuh konsep pedagogi yang diteliti.
\end{abstract}

Kata-kata Kunci: Digital, Konteks, Pandemik, Pedagogi, Teknologi.

\begin{abstract}
The Covid-19 pandemic problem makes learning and teaching not can be implemented face-to-face again, then transferred to the process of distance learning or teaching online. This result in pedagogy also experienced changes, including educators in implementing the learning and teaching process. The purpose of this research is to get a concept appropriate pedagogy to be implemented during the Covid-19 pandemic. Using qualitative research methodologies; conduct qualitative analysis by selecting and researching seven concepts of the latest pedagogical developments in the era digital and research results from journals in the last five years. From the results research can be concluded the need to apply the new relevant concept of Pedagogy in the era digitally in the context of the pandemic Covid-19 by taking important values from the seven pedagogical concepts studied.
\end{abstract}

Keywords: Context, Digital, Pandemic, Pedagogy, Technology. 


\section{PENDAHULUAN}

Perkembangan di era digital saat ini begitu pesat, baik dari sisi pengembangan perangkat keras (hardware) dan perangkat lunak (software) maupun perangkat jaringan (networking). Hal tersebut membuat perangkat teknologi yang dihasilkan menjadi semakin canggih. Untuk konteks sekarang, pada saat seluruh dunia sedang mengalami pandemi Covid-19, berdampak pada masyarakat yang harus menjaga jarak fisik agar tidak tertular oleh virus atau menularkan virus, manfaat pemakaian teknologi saat ini sangatlah dirasakan oleh seluruh elemen masyarakat, termasuk di dalam dunia Pendidikan. Sebelumnya kita lebih banyak menyoroti dampak negatif dari penggunaan teknologi, misalnya membuat mereka kecanduan main games, lebih banyak menghabiskan waktu dengan perangkat teknologinya dari pada mengalokasikan waktu untuk belajar, sehingga prestasi belajar menurun. Perangkat teknologi seperti smartphone yang dahulu dikatakan sebagai menjauhkan yang dekat, namun sekarang kita melihatnya dengan cara pandang yang berbeda, sebab teknologi dapat menjadi alat untuk menolong kita jika dipergunakan dengan tepat, khususnya dalam masa pandemi Covid-19 ini, kita mengatakan mendekatkan yang jauh. Di saat proses belajar dan mengajar tidak lagi dapat dilaksanakan dengan tatap muka, maka dialihkan menjadi proses belajar dan mengajar jarak jauh atau online. Hasil penelitian terbaru terhadap dua puluh negara dalam merespons intra-periode pedagogi digital adalah, kurangnya informasi tentang pendekatan pedagogi dan prinsip yang diadopsi terhadap derasnya perubahan ke pendidikan digital, yang mempunyai potensi untuk memungkinkan lebih fleksibel dan inovatif metodemetode digital dari Pendidikan (Crawford et al., 2020). Oleh sebab itu tulisan mengenai pedagogi di era digital ini ditulis di jurnal.

Jika pada masa lalu, tidak semua tenaga pendidik; guru atau dosen dapat atau mau memakai dan memanfaatkan teknologi, maka pada saat pandemi Covid-19 ini, mau tidak mau semua harus belajar untuk dapat memakai teknologi sebagai alat pedagogi pengganti proses belajar dan mengajar yang selama ini dilakukan secara manual dan tatap muka. Namun sebelum penerapannya, tenaga pendidik perlu mengetahui konsep dan konteks pedagogi di dunia era digital. Untuk itu, maka penulis meneliti dari berbagai pedagogi untuk mendapatkan pemahaman pedagogi yang tepat dan relevan di era digital ini. Penulis memberi judul penelitian ini: Pedagogi di Era Digital Dalam Konteks Pandemi Covid-19. 


\section{TEORI}

Kajian teori penulis berdasarkan kajian pustaka dengan membatasi pada tujuh konsep pedagogi yang terpilih dan melihat dalam konteks pandemic Covid-19 di era digital serta hasil penelitian dan jurnal terkini, untuk mendukung tesis penulis dengan kepustakaan dalam lima tahun terakhir.

\section{Pengertian Pedagogi}

Pedagogi adalah ilmu pendidikan, merupakan salah satu syarat yang penting bagi seorang pendidik. Pedagogi didefinisikan sebagai seni, sains, atau profesi mengajar (Merriam-Webster, n.d.). Pedagogi adalah seni, sains, praktik, dan teori pengajaran, tetapi sama-sama tentang belajar. Belajar hanyalah efek dari mengajar perlu direkontruksi ulang, dan ada kesatuan antara pengalaman dan tindakan belajar dan mengajar. (O'Donald et al., 2015). Pedagogi selalu dua arah, tidak pernah satu arah. Lebih lanjut dalam pedagogi, ada hubungan antara tenaga pendidik dan peserta didik yang tidak bisa dipisahkan. Tenaga pendidik dan peserta didik berinteraksi dengan aktif dan dalam hubungan yang simultan mengajar dan belajar, serta terjalin dengan objek penelitian, maka diperlukan kontekstualisasi sebagai pendekatan untuk pengajaran (O'Donald et al., 2015). Pedagogi dalam istilah teori pendidikan merujuk pada seni (kreatifitas) atau sains (inovasi) pengajaran, proses dan praktik memberikan pengetahuan kepada peserta didik dan memvalidasi pengetahuan peserta didik melalui evaluasi dan penilaian untuk melihat apakah efektif atau tidak. Dalam definisi itu, pedagogi mengacu pada pengajaran yang disengaja dan pembelajaran yang terukur, yang keduanya diasumsikan terjadi di lembaga pendidikan resmi bersama (O'Donald et al., 2015).

\section{Berbagai Macam Pedagogi}

\section{Pedagogi Cerdas}

Pedagogi Cerdas (Smart Pedagogy) untuk pembelajaran yang ditingkatkan dengan teknologi. Istilah 'Smart' telah dipilih untuk mendefinisikan aspek pedagogis pembelajaran yang ditingkatkan oleh teknologi (Daniela, 2019). Pedagogi cerdas adalah kekuatan pendorong pembelajaran yang ditingkatkan melalui teknologi, itu telah menjadi model konseptual dari proses pendidikan. Hasil penelitian mengatakan bahwa pedagogi cerdas dapat mendukung pendidik dalam menemukan jawaban tentang bagaimana mendukung belajar dalam proses pendidikan yang ditransformasikan, bagaimana memasukkan teknologi ke dalam pembelajaran untuk mendukung pengembangan metakognisi, yaitu kesadaran atau analisis proses belajar atau berpikir sendiri, bagaimana mendukung meningkatkan pengetahuan, bagaimana mendukung pengembangan kompetensi digital dan sebagainya. Semua ini menunjukkan perlunya landasan arah baru pedagogi, yang didefinisikan sebagai 
pedagogi cerdas, untuk memastikan penggunaan teknologi digital yang berbeda secara cerdas (Daniela, 2019).

\section{Pedagogi Kultur Populer}

Televisi, musik, media sosial, film-film, dan lain sebagainya adalah komponenkomponen yang sangat memengaruhi kultur populer, yang dapat berdampak bagaimana orang berinteraksi satu sama lainnya. Dalam sebuah penelitian yang mengambil salah satu contoh dari Film Lego, disimpulkan bahwa film Lego dapat dilihat sebagai alat media yang mendorong pemirsanya untuk menjadi bagaikan seorang yang memimpin proyek dan menghasilkan pola komunitas baru dengan mendekonstruksi dan merekonstruksi bagian-bagian yang tersedia, setelah mereka dapat melihat kegunaan semua bagian. Film ini menggambarkan perkembangan kompleks kesadaran sosial tidak hanya dalam satu individu, tetapi juga di seluruh komunitas, itulah keindahan dan keunikan film tersebut (Jubas et al., 2015). Tentu tidak semua film mempunyai nilai pendidikan yang baik, oleh sebab itu perlu diseleksi, manakah film yang dapat dipakai sebagai alat untuk mengajar.

\section{Pedagogi Inovatif}

Menjadi inovatif dan kewirausahaan adalah tentang percaya bahwa seseorang dapat membuat perbedaan dan melalui tindakan seseorang mengubah suatu situasi. Kompetensi kewirausahaan dan inovasi dominan tercermin dalam pendidikan, mengenai bagaimana seseorang mengatur dan menangani peluang, dan mengembangkan ide-ide baru dan cara-cara baru dalam melakukan sesuatu dalam berbagai kegiatan. (Chemi et al., 2017). Semua pengaturan pendidikan dan yang mengubah proses, penilaian dan desain pembelajaran yang inovatif dapat membangkitkan terwujudnya berbagai macam ekspresi emosional, secara keseluruhan, penelitian menunjukkan pentingnya lingkungan belajar yang kaya di lembaga-lembaga pendidikan mengakui kualitas emosional dari interaksi manusia, menyambut berbagai ekspresi manusia dan pada saat yang sama mengingat bahwa emosi secara budaya (Chemi et al., 2017).

\section{Pedagogi Kasih}

Kadang kala para tenaga pendidik itu dianggap menakutkan bagi para siswa, seringkali muncul istilah: guru atau dosen killer. Hal ini mengakibatkan relasi kurang terpelihara dan suasana proses belajar mengajar penuh ketakutan. Pedagogi kasih dapat diterapkan untuk masa-masa yang menakutkan, cara mengajar dan belajar yang sama-sama mengatakan kebenaran tentang ketakutan kita, dan membentuk kita untuk merespons dengan cara yang bijaksana dan bermanfaat. Ini bukan teknik atau serangkaian praktik terbaik yang dapat diunduh dan diimplementasikan: masalah dipecahkan. Ini bukan tentang menjadi tenaga pendidik yang lebih baik, atau bahkan menjadi orang yang lebih baik. Ini adalah cara — jalan, undangan - 
untuk menjadi diri Anda sebagaimana adanya, untuk percaya bahwa Anda cukup baik, dan untuk membagikan diri Anda yang sejati dan sejati dengan siswa Anda (Paris, 2016). Pedagogi kasih menghargai solidaritas sehingga menumbuhkan komunitas belajar, dan akhirnya menumbuhkan harapan dan imaginasi di semua peserta didik untuk memiliki daya tahan meskipun ada hambatan (Luguetti et al., 2019).

\section{Pedagogi Adaptasi}

Yesus mengambil sikap adaptasi pedagogis yang sama yang telah menandai interaksinya dengan orang lain di seluruh Injil. Secara khusus, dialog-Nya dengan Petrus menantang pemahaman murid dan komitmen kepada-Nya, yang merupakan bagian dari skema pedagogik Yesus yang lebih besar (Sturdevant, 2016). Adaptasi terbesar adalah inkarnasi-Nya. Allah menjadi manusia, Allah sebagai penuntun jiwa yang bisa beradaptasi. Pemuridan dilaksanakan tidak statis, namun merupakan suatu proses sesuai dengan kapasitasnya.

\section{Pedagogi Teologi Hidup}

Pedagogi Teologi Hidup adalah pengajaran tentang panggilan Kristen dan pencarian arti (Marsh et al., 2016). Kita dipanggil dan diperlengkapi di dalam Kristus untuk mengasihi dan melayani sesama. Apa yang kita nyatakan mempertajam apa yang kita lakukan dan bagaimana kita bertindak dan hidup di dalam dunia ini. Lebih dari hal di atas, Teologi hidup sebagai metodologi menjadikan ruang bagi semua peserta didik untuk memiliki dan menemukan suara mereka, karena teologi hidup mengundang mereka untuk membawa kekhasan dan rincian pengalaman hidup mereka sendiri ke meja (Marsh et al., 2016).

\section{Pedagogi Shalom}

Shalom adalah kata Ibrani, sering digunakan dalam Alkitab Ibrani, dan biasanya diterjemahkan sebagai "damai." Kapasitas tenaga pendidik yang baru adalah tenaga pendidik yang menggunakan karunianya, pelatihannya, dan kasihnya pada peserta didik, sebagai pembawa shalom (Lee \& Kaak, 2017). Dalam penerapannya, ketika kita menciptakan shalom melalui penilaian keanekaragaman, kita menciptakan lingkungan belajar yang otentik dan inklusif. Lingkungan belajar tersebut sangat menyenangkan dan mengasyikkan serta memberikan peserta didik landasan yang kuat untuk kesuksesan dan kepuasan. Sebagai pendidik Kristen, mandat moral kita adalah untuk menjadi bijak dan berani. Menyusun pengalaman belajar yang merupakan contoh keberagaman tindakan yang penuh dengan shalom (Lee \& Kaak, 2017). Yesus Kristus adalah contoh pedagogi shalom yang dapat kita teladani. Penelitian menunjukkan bahwa metode pengajaran Yesus Kristus mendukung penelitian saat ini dalam pengajaran yang efektif. Metode Yesus memakai instruksi yang berbeda, tantangan kognitif, keterlibatan peserta didik, pertanyaan yang efektif, 
dan relevan. Sebagai tenaga pendidik yang adalah orang Kristen, kita akan melakukannya dengan baik dengan mengikuti teladan Kristus dan mengikuti metode pengajaran-Nya. Seperti halnya Kristus, tugas kita adalah untuk hidup diutus, mempromosikan shalom di kelas dengan cara efektif berhubungan dengan peserta didik (Lee \& Kaak, 2017).

\section{Pendidik dan Murid}

Ada ratusan alat teknologi digital yang beragam untuk mendukung pengajaran dan pembelajaran. Namun, ketersediaan yang luar biasa ini menimbulkan tantangan bagi pendidik sehubungan dengan pilihan alat dan belajar bagaimana memanfaatkannya dalam pengajarannya ( $\mathrm{Ng}$, 2015). Pengajaran yang baik masih merupakan pusat integrasi teknologi yang efektif jika menggunakan teknologi untuk mencapai hasil pembelajaran yang sukses. Kesediaan para tenaga pendidik untuk menginvestasikan waktu untuk secara profesional belajar tentang integrasi teknologi secara sistematis, diatur sendiri adalah langkah pertama yang penting dalam keberhasilan penggunaan teknologi dalam pengajaran mereka $(\mathrm{Ng}, 2015)$.

Tenaga Pendidik perlu memperhatikan konteks di era digital, sehingga dapat menyesuaikan diri dan pedagogi di dalam proses belajar dan mengajar. Ada tantangan dalam melibatkan para peserta didik dalam pembelajaran yang bermanfaat dengan menggunakan teknologi digital dan menghilangkan kebiasaan yang buruk karena menggunakan teknologi dengan tidak tepat, jangan sampai diperalat oleh teknologi, tetapi memakai teknologi sebagai alat. Hasil penelitian mengatakan tenaga pendidik juga harus diperlengkapi dengan keterampilan dalam pembinaan dan merancang pembelajaran yang bermakna dengan menggunakan teknologi digital sehingga hasil pembelajaran yang diinginkan akan berhasil dicapai (Sailin \& Mahmor, 2018). Hasil penelitian yang lain mengingatkan bahwa semua pendekatan ini, untuk literasi media adalah tentang belajar, tetapi tidak satupun dari mereka menawarkan kedalaman pemahaman dan koneksi ke dunia kehidupan peserta didik sebagai studi literasi media kritis. Menjadi masyarakat yang semakin global, menjadi semakin penting bagi peserta didik untuk memahami apa yang sedang terjadi karena dampak dari peristiwa yang dialami secara global (Robertson \& Scheidler-Benns, 2016).

\section{Era Digital}

Daniel Ronda menyebutkan, era digital adalah era baru. Dunia nyata dan digital tidak lagi berbeda. Keduanya adalah kesatuan yang tidak dapat dipisahkan (Ronda, 2016, 189). Terdapat beberapa hal yang menunjukkan perkembangan era ke era digital. 


\section{Industri 4.0}

Istilah Industri 4.0 pertama kali diperkenalkan di Jerman sekitar 2011 dan artinya Revolusi Industri keempat. Revolusi Industri pertama adalah Mekanisasi dimungkinkan melalui penggunaan tenaga uap dan air yang mengarah pada peningkatan efisiensi. Revolusi Industri kedua ditandai melalui Produksi Massal barang, seperti ban berjalan untuk mobil oleh Henry Ford. Revolusi Industri ketiga didorong oleh Komputerisasi dan Otomasi dari proses produksi. Revolusi Industri keempat sekarang adalah fase berikutnya dalam Digitalisasi dan Jaringan yang diterapkan pada sektor manufaktur. Kembar digital yang disebut semua aset di perusahaan - mesin, bahan, orang - memungkinkan simulasi semua proses dari desain hingga produksi hingga akhir masa pakai produk. Pemasok dan pelanggan juga terhubung secara digital dalam Proses Cerdas serta Produk Cerdas mengumpulkan data tentang penggunaannya. Semua ini dapat mengaktifkan Layanan Cerdas (Fathi et al., 2019).

\section{Society $\mathbf{5 . 0}$}

Istilah "masyarakat 5.0" pertama kali muncul di Jepang pada 2016. Sejak itu, telah menyebar dan konsep dasarnya terus dibentuk. Masyarakat 5.0 adalah istilah yang digunakan dalam Rencana Dasar Ilmu Pengetahuan dan Teknologi Kelima, ditinjau oleh Dewan Ilmu Pengetahuan, Teknologi, dan Inovasi Pemerintah Jepang. Itu diberlakukan oleh Kabinet Menteri Jepang pada Januari 2016 (Salgues, 2018). Manufaktur bukan di pusat, tetapi seluruh masyarakat. Masyarakat 5.0 atau Masyarakat Super Cerdas, yang diperkenalkan dalam Rencana Dasar kelima untuk Sains dan Teknologi, dicirikan melalui Teknologi Informasi (TI), khususnya Kecerdasan Buatan, yang akan mengubah banyak hal dalam bisnis dan kehidupan sehari-hari (Salgues, 2018).

\section{Teknologi Digital}

Teknologi digital beragam dan alasan penggunaannya beragam pula. Dalam konteks ini, termasuk bagian dari teknologi elektronik yang mencakup perangkat keras dan perangkat lunak yang digunakan oleh individu untuk tujuan pendidikan, sosial dan atau hiburan dalam konteks formal dan informal dalam kehidupan seharihari mereka. Teknologi digital di pendidikan, juga disebut sebagai teknologi pendidikan meliputi: komputer desktop; perangkat seluler seperti laptop, tablet, ultramobiles, ponsel, ponsel pintar, PDA, dan konsol game; alat perekam digital seperti kamera, perekam suara dan video; peralatan pencatatan data dan probe terkait; papan tulis interaktif (juga disebut SmartBoards); Teknologi Web 2.0 dan sumber daya online lainnya ( $\mathrm{Ng}, 2015)$. Model "alat standar" Teknologi Informasi dan Komunikasi, dapat menekankan kesesuaian antara teknologi dan pedagogi, baik memilih atau mengembangkan pedagogi agar sesuai dengan teknologi atau memilih teknologi yang sesuai dengan pedagogi. Ada berbagai pendekatan untuk 
mempelajari teknologi yang berusaha menangkap kompleksitas ini untuk tujuan yang berbeda, dengan cara yang berbeda dan pada tingkat yang berbeda (Creanor \& Walker, 2012). Dalam menggunakan teknologi digital untuk pendidikan, pembelajaran profesional yang efektif adalah tentang mengembangkan secara sistematis dan membangun literasi digital yang ada untuk memungkinkan pendidik memperoleh kepercayaan diri dan kapasitas untuk merencanakan strategi pedagogis yang akan membantu peserta didik untuk belajar dengan sukses ( $\mathrm{Ng}, 2015)$. Mengajar dengan teknologi memerlukan penyesuaian, sebab mengajar dengan teknologi itu rumit dan tidak ada jalan pintas dalam pengembangan dan implementasi penggunaan teknologi yang baik dan efektif $(\mathrm{Ng}, 2015)$.

\section{Pendidikan Jarak Jauh}

Pendidikan terbuka dan jarak jauh, telah berevolusi melalui beberapa tahapan sejarah, dari pendidikan korespondensi ke penggunaan media cetak, radio, dan TV, hingga penggunaan telekonferensi, komputer dan multimedia, dan seterusnya hingga pembelajaran online, termasuk kursus terbuka masif online. Sifatnya kompleks ruang lingkupnya karena melibatkan berbagai cara pengajaran dan pembelajaran non-tradisional yang dimediasi oleh berbagai media dan teknologi (Jung, 2019). Saat ini Pendidikan jarak jauh memanfaatkan aplikasi teknologi video conferencing yang tersedia seperti: ZOOM, Google Meet, Microsoft Teams, Cisco Webex, WhatsApp, Jitsi, dan lain sebagainya.

\section{Keamanan dan Privasi}

Salah satu hal yang sangat penting dalam penerapan pendidikan di era digital adalah masalah keamanan dan privasi. Dalam konteks sekarang kita mendapatkan berita bahwa ada pemakaian aplikasi komunikasi jarak jauh yang disinyalir kurang aman, dapat disusupi oleh orang yang tidak bertanggungjawab. Berkaitan juga dengan keamanan data rekaman dan privasi kita sebagai pemakai yang dapat disalahkan gunakan atau dijual. Masalah keamanan dan privasi telah menjadi isu yang penting dalam komunikasi di era digital. Di Indonesia telah ada peraturan menteri yang melindungi data pribadi dalam sistem elektronik (Menkoinfo, n.d.).

\section{Konteks Pandemi}

Menurut organisasi kesehatan dunia, pada saat tulisan ini dibuat, telah ada 3.976.043 orang terinfeksi virus corona (covid-19) dan 277.708 orang yang mati karena virus ini, dan penyebarannya telah meluas hingga 215 negara (World Health Organization, n.d.). Sedangkan di Indonesia, ada 14.265 orang positif kena virus corona, 2.881 orang sembuh, dan 991 orang meninggal dunia (Gugus Tugas, n.d.). Oleh karena itu, pemerintah menerapkan Pembatasan Sosial Berskala Besar (PSBB). Selama PSBB ada larangan perjalananan lintas wilayah, dan adanya pembatasan jarak fisik satu sama lain supaya penyebaran virus dapat dihambat. Kondisi ini 
mengakibatkan proses belajar dan mengajar yang sebelumnya diselenggarakan tatap muka berubah menjadi kuliah jarak jauh atau online.

\section{METODE}

Metode penelitian ini bersifat kualitatif; melakukan analisis kualitatif dengan memilih dan meneliti tujuh konsep perkembangan pedagogi terbaru di era digital dan hasil penelitian dari jurnal-jurnal dalam lima tahun terakhir, sehingga didapat konsep baru yang relevan, Pedagogi di era digital dalam konteks pandemi Covid-19 dengan mengambil nilai-nilai penting dari ketujuh konsep pedagogi yang diteliti.

\section{HASIL DAN PEMBAHASAN}

\section{Padagogi di Era Digital pada Masa Pandemi Covid-19}

\section{Pedagogi}

Pedagogi adalah seni, sains, praktik dalam proses belajar dan mengajar. Dengan adanya pengaruh teknologi di era digital, maka pedagogi juga mengalami perubahan.

Tabel 1. Pedagogi di Era Digital

\begin{tabular}{|c|c|c|c|}
\hline No. & Pedagogi & Keterangan & Pembahasan \\
\hline 1 & Smart & $\begin{array}{l}\text { Pedagogi menjadi Smart } \\
\text { Pedagogi, dapat } \\
\text { meningkatkan proses } \\
\text { belajar dan mengajar. }\end{array}$ & $\begin{array}{l}\text { Pedagogi yang cerdas sesuai } \\
\text { perkembangan teknologi, misalnya } \\
\text { handphone menjadi smartphone. }\end{array}$ \\
\hline 2 & Kultur Populer & $\begin{array}{l}\text { Kultur Populer bersifat } \\
\text { kekinian, yang ada di } \\
\text { dalam masyarakat. }\end{array}$ & $\begin{array}{l}\text { Pedagogi juga perlu melihat } \\
\text { konteks kultur popular ini, dan } \\
\text { menyesuaikan menjadi Pedagogi } \\
\text { Kultur Populer, misalnya, peneliti } \\
\text { yang menggunakan sebuah film } \\
\text { untuk mengajarkan nilai-nilai } \\
\text { tertentu. }\end{array}$ \\
\hline 3 & Inovatif & $\begin{array}{l}\text { Tenaga pendidik perlu } \\
\text { mempunyai inovasi } \\
\text { dalam penemuan- } \\
\text { penemuan baru dalam } \\
\text { mengajar dengan } \\
\text { berbagai cara yang baru, } \\
\text { yang disebut sebagai }\end{array}$ & $\begin{array}{l}\text { Tenaga Pendidik biasanya terjebak } \\
\text { pada pola lama sesuai dengan } \\
\text { pengalamannya yang lalu, namun } \\
\text { pengajaran saat ini tentu } \\
\text { mengalami perubahan besar, } \\
\text { sehingga tidak dapat memakai } \\
\text { pola lama lagi. }\end{array}$ \\
\hline
\end{tabular}




\begin{tabular}{|c|c|c|c|}
\hline & & Inovatif Pedagogi. & \\
\hline 4 & Kasih & $\begin{array}{l}\text { Pada masa yang lalu } \\
\text { banyak peserta didik } \\
\text { masuk kelas dengan } \\
\text { perasaan takut, relasi } \\
\text { tenaga pendidik dan } \\
\text { peserta didik kurang } \\
\text { baik. }\end{array}$ & $\begin{array}{l}\text { Semestinya hal tersebut sudah } \\
\text { tidak ada lagi dan diganti dengan } \\
\text { suasana yang baik, sehingga setiap } \\
\text { peserta didik dapat menjadi } \\
\text { seperti dirinya tanpa rasa takut, } \\
\text { tetapi memiliki relasi yang baik. } \\
\text { Oleh sebab itu diperlukan } \\
\text { pedagogi kasih. }\end{array}$ \\
\hline 5 & Adaptasi & $\begin{array}{l}\text { Tenaga pendidik perlu } \\
\text { mengadakan adaptasi. }\end{array}$ & $\begin{array}{l}\text { Jika Tuhan Yesus mengadaptasi } \\
\text { dengan cara menjadi manusia, } \\
\text { maka kita sebagai tenaga pendidik } \\
\text { pun perlu beradaptasi untuk } \\
\text { melaksanakan proses belajar dan } \\
\text { mengajar sesuai dengan konteks } \\
\text { masa kini, dengan menggunakan } \\
\text { pedagogi adaptasi. }\end{array}$ \\
\hline 6 & Teologi Hidup & $\begin{array}{l}\text { Kita perlu memenuhi } \\
\text { panggilan Allah dan } \\
\text { menjalaninya dalam } \\
\text { kehidupan kita } \\
\text { sebagaimana kita ada. }\end{array}$ & $\begin{array}{l}\text { Dengan adanya berbagai } \\
\text { pedagogi yang sesuai konteks } \\
\text { masa kini, perlu diperhatikan } \\
\text { jangan sampai kehilangan arah } \\
\text { dalam hidup. Kita perlu memenuhi } \\
\text { panggilan Allah dan menjalaninya } \\
\text { dalam kehidupan kita } \\
\text { sebagaimana kita ada dengan } \\
\text { Pedagogi Lived Theology. }\end{array}$ \\
\hline 7 & Shalom & $\begin{array}{l}\text { Membawa Shalom, } \\
\text { damai. }\end{array}$ & $\begin{array}{l}\text { Sesuai dengan tugas dari Tuhan } \\
\text { Yesus, yaitu membawa damai, } \\
\text { shalom dalam hidup kita untuk } \\
\text { semua orang. Kita memerlukan } \\
\text { pedagogi yang membawa shalom } \\
\text { yang meneladani Tuhan Yesus } \\
\text { Kristus. }\end{array}$ \\
\hline
\end{tabular}

Hasil penelitian mengatakan, pelajar milenial mendorong tenaga pendidik untuk beralih dari pedagogi lama ke pedagogi koneksi. Konservatisme tenaga pendidik memutus hubungan mereka dari pelajar milenial. Pedagogi koneksi membutuhkan tenaga pendidik untuk merangkul semangat peralihan dunia digital. Meskipun memiliki aksen pra-digital, para tenaga pendidik progresif ini menyatakan kesediaan untuk menghadapi kaum milenial sebagai generasi penghubung. Hasil penelitian mengingatkan bahwa akses peserta didik ke teknologi bisa menjadi pengalih perhatian daripada peningkatan. Perhatian peserta didik dapat terganggu dan lingkungan belajar sebenarnya terhambat. Ini adalah konteks bagaimana teknologi 
dapat digunakan dan mengapa teknologi digunakan, itu yang penting. Tetapi Lebih lanjut dikatakan bahwa teknologi telah memberikan peluang bagi peserta didik dan tenaga pendidik untuk meningkatkan lingkungan belajar dan mengajar. Alat teknologi perlu dipeluk tetapi bukan jawaban atau satu-satunya cara untuk mengajar peserta didik modern kita (Blissenden, 2015). Seorang tenaga pendidik yang dianggap sebagai profesional di era digital tidak hanya memiliki kemampuan dalam pendidikan dan menguasai teknologi pendidikan, tetapi juga kemampuan atau memiliki kecerdasan intrapersonal, intelektual, emosional dan spiritual. Oleh karena itu, penghargaan yang diberikan kepada tenaga pendidik akan cukup, dan tidak ada lagi tenaga pendidik yang harus memiliki pekerjaan ganda atau menggeluti pekerjaan lain. Tentunya dengan kualitas tenaga pendidik yang baik di era digital akan memudahkan peserta didik untuk melakukan proses pembelajaran (Fanreza, 2018). Tenaga pendidik dapat merancang pembelajaran yang memiliki relevansi dengan peserta didik milenial. Pembelajaran berbasis masalah, misalnya, menggairahkan kaum milenial karena hal itu menghubungkan mereka dengan masalah-masalah kehidupan nyata. Itu dapat mengubah belajar menjadi kegiatan yang menyenangkan. Tenaga Pendidik harus mengklarifikasi tujuan pembelajaran yang bertujuan mengubah digital selfhood dan dunia mereka (Andalas, 2019). Dengan demikian pembelajaran kepada para peserta didik akan lebih aktif, kreatif, efektif dan menyenangkan. Hasil penelitian mengatakan dukungan lembaga sebagai lingkungan kerja yang membantu dalam menerapkan inovasi teknologi pedagogi dalam semangat era digital sangat penting dalam membangun identitas profesional pendidik guru dan dalam memahami dan menerapkan inovasi pedagogis dalam pelatihan tenaga pendidik. (Avidov-Ungar \& Forkosh-Baruch, 2018).

\section{Era Digital}

Saat ini kita akan dan telah mengalami perubahan dari Industry 4.0 ke Society 5.0, Manufaktur bukan di pusat lagi, tetapi seluruh masyarakat. Masyarakat 5.0 atau Masyarakat Super Cerdas, yang diperkenalkan dalam Rencana Dasar kelima untuk Sains dan Teknologi, dicirikan melalui Teknologi Informasi (TI), khususnya Kecerdasan Buatan, yang akan mengubah banyak hal dalam bisnis dan kehidupan sehari-hari. Oleh sebab itu akan berdampak kepada dunia Pendidikan juga, di mana sains dan teknologi, khususnya kecerdasan buatan. Hal ini membuktikan pedagogi pun harus mengikuti perubahan. Pendapat di atas sesuai dengan hasil penelitian yang mengatakan bahwa prinsip pedagogi digital perlu memperhatikan: penggunaan Teknologi Informasi dan Komunikasi dalam beragam bentuk; membangun pola pikir terintegrasi para tenaga pendidik melalui kombinasi sumberdaya manusia dan Teknologi Informasi dan Komunikasi; kesadaran pada tenaga pendidik untuk mengembangkan melalui teknologi; menciptakan kondisi untuk pembangunan spiritual dan kreativitas para pendidik dan peserta didik; dan diperlukan evaluasi kualitas dari proses Pendidikan (Bykov \& Leshchenko, 2016). Oleh karena mengajar dengan teknologi itu rumit dan tidak ada jalan pintas dalam pengembangan dan 
implementasi penggunaan teknologi yang baik dan efektif, maka perlu mengembangkan secara sistematis dan membangun literasi digital yang ada untuk memungkinkan tenaga pendidik memperoleh kepercayaan diri dan kapasitas untuk merencanakan strategi pedagogis yang akan membantu peserta didik untuk belajar dengan sukses. Belajar jarak jauh bukan suatu hal yang tabu lagi sekarang, tetapi banyak manfaat yang didapatkan. Demikian juga pemerintah mendukung pembelajaran jarak jauh. Aksesibilitas internet dalam istilah budaya sendiri melampaui negara dan etnis untuk memasukkan etnis, ras, kelas, jenis kelamin, dan disabilitas dalam identitas sosial seseorang. Komunikasi online yang dapat diakses menyediakan sumber informasi penting bagi penyandang disabilitas. Text-to speech dan alt. program deskriptif untuk visual memungkinkan orang yang buta untuk mengakses informasi jauh lebih mudah dengan online daripada di dunia fisik. Orang dengan identitas sosial yang berbeda dari norma dapat berpartisipasi dalam kelas online dan diskusi tanpa mengurangi cara menilai orang lain menerima pesan mereka (Elliott \& Spence, 2017). Hal terakhir di era digital yang perlu diperhatikan adalah berkaitan dengan keamanan dan privasi (security and privacy).

\section{Konteks Pandemi Covid-19}

Konteks sekarang, pada saat seluruh dunia sedang mengalami pandemi Covid19, berdampak pada masyarakat yang harus menjaga jarak fisik agar tidak tertular oleh virus atau menularkan virus, manfaat pemakaian teknologi saat ini sangatlah dirasakan oleh seluruh elemen masyarakat, termasuk di dalam dunia Pendidikan. Di saat proses belajar dan mengajar tidak lagi dapat dilaksanakan dengan tatap muka, maka dialihkan menjadi proses belajar dan mengajar jarak jauh atau online. Contoh pengajaran dalam konteks pandemi ini: Peserta didik diberi tugas oleh tenaga pendidik secara online (bukan di kelas) untuk membuat sebuah video mengenai apa yang harus dilakukan selama masa pandemi ini, lalu diminta video tersebut diunggah ke situs video youtube, kemudian akan dinilai oleh tenaga pendidiknya secara online. Hasilnya, peserta didik kemudian merekam sendiri dengan smartphone, mereka memberikan peragaan dan komentar bagaimana mencuci tangan, memakai masker, menjaga jarak fisik, dan makan dengan menu yang sehat. Setelah selesai, video tersebut diunggap ke situs video youtube dan kemudian dinilai oleh tenaga pendidiknya. Peserta didik sangat cepat belajar dalam mempergunakan teknologi karena mereka lahir di era digital, berbeda dengan para tenaga pendidik yang agak tertatih-tatih belajar mempergunakan teknologi karena tidak dilahirkan di era digital. Kepercayaan diri peserta didik terbentuk, menjadi lebih kreatif, dan tugas pelajaran menjadi hal yang menyenangkan bagi mereka. Konteks pandemi Covid-19 saat ini semakin mendorong dan mempercepat pemakaian teknologi dalam proses belajar dan mengajar. Kalau dahulu teknologi dikatakan sebagai penyebab masalah: 'menjauhkan yang dekat' (contohnya ketika sedang kuliah di kelas, peserta didik sibuk main smartphone namun pikirannya jauh, tidak ada di dalam kelas), tetapi sekarang berubah menjadi: 'mendekatkan yang jauh' (contohnya karena tenaga 
pendidik tidak bisa hadir di kelas untuk tatap muka karena pandemi, dengan teknologi video conferencing dapat hadir di kelas secara online). Para tenaga pendidik harus menyesuaikan pedagoginya dengan konteks yang ada, misalkan belajar untuk membuat materi pelajaran dalam bentuk rekaman video, diperlukan seni dan kreatifitas, dan membuat agar materi pembelajaran dan aktifitas tersebut menyenangkan bagi para peserta didik, sehingga aktif terlibat dalam proses belajar mengajar dan dapat menyerap semua materi yang disampaikan, sehingga tujuan pembelajaran dapat tercapai. Pedagogi di era digital atau online itu perlu diimplementasikan, sesuai hasil penelitian terakhir pada masa pandemi covid-19 di duapuluh negara menyimpulkan perlunya pedagogi online. Dikatakan sementara banyak organisasi pendidikan tinggi di negara-negara di mana sekolah ditutup pada awalnya berfokus pada transisi ke lingkungan online, fokusnya sekarang pada pedagogi online. Belum pernah ada waktu untuk tanggapan global yang terkoordinasi, kolaboratif, dan kolektif terhadap prinsip-prinsip praktik terbaik untuk pengajaran online. Dan di masa krisis global, ada peluang untuk sumber daya dan keahlian bersama di seluruh dunia untuk memastikan pendidikan peserta didik dapat berlanjut dalam menghadapi Covid-19 (Crawford et al., 2020). Konteks pandemi bukan hanya pada kota-kota besar, namun pada daerah-daerah pedesaan yang mungkin sebagian besar belum terjangkau jaringan internet, sehingga tidak dapat memakai teknologi jaringan yang terhubung online. Oleh sebab itu perlu dimulai dengan penggunaan teknologi digital secara bertahap sampai tahap di mana infrastruktur sudah siap.

\section{KESIMPULAN}

Pertama, tenaga pendidik yang tidak lahir di era digital perlu memiliki konsep pedagogi di era digital, dan mendapat pelatihan untuk menggunakan perangkat teknologi dalam melaksanakan proses belajar mengajar, serta mengadakan perubahan sesuai dengan konteks pandemi covid-19 di era digital. Konsep-konsep yang baik didapat dari ketujuh pedagogi: pedagogi yang cerdas, berhubungan dengan kultur popular, ada ide-ide baru yang inovatif, memiliki relasi dengan kasih, beradaptasi dalam konteks di era digital, mengajarkan teologi hidup yang membawa kekhasan dan rincian pengalaman hidup peserta didik sendiri, dan sebagai pembawa damai (shalom), dapat memperlengkapi tenaga pendidik untuk melihat dari berbagai sudut pandang penting dan bagaimana konsep pedagogi di era digital itu dapat diterapkan pada masa pandemi Covid-19 saat ini, walaupun dari jarak jauh, namun hubungan tenaga pendidik dan peserta didik tetap terjalin dekat.

Kedua, dalam melaksanakan penerapan teknologi di era digital, kita perlu memperlajari dan memperhitungkan, apakah pedagodi kita menyesuaikan diri dengan teknologi, atau kita memakai teknologi untuk menyesuaikan dengan

pedagogi kita. Hal yang lain adalah semua implementasi peralatan teknologi dan sumber daya manusia yang menanganinya perlu investasi, oleh sebab itu ketersediaan dana juga harus diperhitungkan sesuai dengan Return of Investment 
(ROI). Penerapan, khususnya di sekolah-sekolah teologi tidaklah mudah, hal ini disebabkan rata-rata semua sekolah teologi adalah non-profit, oleh sebab itu diperlukan dukungan dana dari luar dan implementasi bertahap yang bijaksana.

Ketiga, tantangan dan peluang, terbuka kepada kita semua, khususnya pada masa pandemi Covid-19 ini yang membuat kita terkejut, tidak siap, bahkan panik. Apakah kita menjawab tantangan ini sebagai peluang untuk meningkatkan pedagogi kita di era digital ini, atau tetap pada konsep pedagogi yang lama. Namun harus diakui dalam konteks di Indonesia, khususnya di pedesaan saat ini, banyak daerah pedesaan yang belum terjangkau infrastuktur yang menyediakan akses internet, oleh sebab itu perlu implementasi yang bertahap, mulai dari teknologi digital tanpa online, sedangkan proses belajar mengajar online baru dapat terlaksana jika infrastruktur sudah siap.

\section{Rekomendasi}

Rekomendasi bagi pendidikan secara umum, kita perlu menerapkan konsep baru pedagogi di era digital dalam konteks pandemi Covid-19. Melengkapi peralatan teknologi, baik itu software, hardware dan networking untuk memungkinkan terselenggaranya proses belajar mengajar online. Memberikan pelatihan kepada tenaga pendidik untuk mempergunakan aplikasi online, dan membuat materi pengajaran online, sehingga proses belajar mengajar tetap dapat dilaksanakan dengan baik di masa pandemi Covid-19 ini.

Rekomendasi bagi pendidikan Kristen secara khusus, selain hal yang telah disebutkan di atas, kita mengikuti teladan Kristus dan mengikuti metode pengajaranNya. Konsep pengajaran Tuhan Yesus tetap relevan sebagai implikasi konsep yang ditawarkan untuk diintegrasikan dalam pedagogi di era digital dalam konteks pandemi Covid-19 antara lain, beradaptasi dengan kemajuan teknologi, membawa shalom agar tenaga pendidik dan peserta didik memiliki relasi yang baik dalam kasih Kristus, sehingga menciptakan suasana belajar mengajar yang menyenangkan, serta tidak melupakan panggilan hidup kita. Dengan demikian proses belajar mengajar tetap dapat dilaksanakan dengan baik di masa pandemi Covid-19 ini.

\section{KEPUSTAKAAN}

Andalas, P. (2019). Connection Pedagogy: A Pedagogical Shift for Millennial Learners in the Digital Era. Proceedings of the 6th International Conference on Educational Research and Innovation (ICERI 2018), 330 (Iceri 2018), 434-439. https://doi.org/10.2991/iceri-18.2019.91.

Avidov-Ungar, O., \& Forkosh-Baruch, A. (2018). Professional identity of teacher educators in the digital era in light of demands of pedagogical innovation. Teaching and Teacher Education, 73, 183-191. https://doi.org/10.1016/j.tate.2018.03.017. 
Blissenden, M. (2015). Teaching Undergraduate Law Students in the 21st Century Pedagogy in a Technological Era. Athens Journal of Law, 1(4), 213-220.

https://doi.org/10.30958/ajl.1-4-2.

Bykov, V. Y., \& Leshchenko, M. P. (2016). Digital Humanistic Pedagogy: Relevant Probelms of Scientific Research in the Field of Using ICT in Education. Information Technologies and Learning Tools, 53(3), 1. https://doi.org/10.33407/itlt.v53i3.1417.

Chemi, T., Davy, S. G., \& Lund, B. (2017). Innovative Pedagogy. In T. Chemi, S. G. Davy, \& B. Lund (Eds.), Innovative Pedagogy. SensePublishers. https://doi.org/10.1007/978-94-6300-968-3.

Crawford, J., Butler-henderson, K., Rudolph, J., Malkawi, B., Glowatz, M., Burton, R., \& Lam, S. (2020). COVID-19: 20 countries' higher education intra-period digital pedagogy responses. Journal of Applied Learning \& Teaching, 3(1). https://doi.org/10.37074/jalt.2020.3.1.7.

Creanor, L., \& Walker, S. (2012). Exploring the Theory, Pedagogy and Practice of Networked Learning. In L. Dirckinck-Holmfeld, V. Hodgson, \& D. McConnell (Eds.), Exploring the Theory, Pedagogy and Practice of Networked Learning. Springer New York. https://doi.org/10.1007/978-1-4614-0496-5.

Daniela, L. (2019). Didactics of Smart Pedagogy. In L. Daniela (Ed.), Didactics of Smart Pedagogy: Smart Pedagogy for Technology Enhanced Learning. Springer International Publishing. https://doi.org/10.1007/978-3-030-01551-0.

Elliott, D., \& Spence, E. H. (2017). Ethics for a Digital Era. In Ethics for a Digital Era. John Wiley \& Sons, Ltd. https://doi.org/10.1002/9781118968888.

Fanreza, R. (2018). The Quality of Teachers in Digital Era. Proceedings of the 5th International Conference on Community Development (AMCA 2018). https://doi.org/10.2991/amca-18.2018.128.

Fathi, M., Khakifirooz, M., \& Pardalos, P. M. (Panos M. . (2019). Optimization in large scale problems Industry 4.0 and Society 5.0 applications (M. Fathi, M. Khakifirooz, \& P. M. (Panos M. . Pardalos (eds.)).

Gugus Tugas. (n.d.). Beranda | Gugus Tugas Percepatan Penanganan COVID-19. https://covid19.go.id/.

Jubas, K., Taber, N., \& Brown, T. (2015). Popular Culture as Pedagogy. In K. Jubas, N. Taber, \& T. Brown (Eds.), Popular Culture as Pedagogy: Research in the Field of Adult Education (Vol. 95). SensePublishers. https://doi.org/10.1007/978-946300-274-5.

Jung, I. (2019). Open and Distance Education Theory Revised: Implications for the Digital Era (l. Jung (ed.)). Springer.

Lee, H., \& Kaak, P. (Eds.). (2017). The Pedagogy of Shalom. Springer Singapore. https://doi.org/10.1007/978-981-10-2987-5.

Luguetti, C., Kirk, D., \& Oliver, K. L. (2019). Towards a pedagogy of love: exploring preservice teachers' and youth's experiences of an activist sport pedagogical 
model. Physical Education and Sport Pedagogy.

https://doi.org/10.1080/17408989.2019.1663499

Marsh, C., Peter, S., \& Azaransky, S. (Eds.). (2016). Lived Theology: New Perspectives on Method, Style, and Pedagogy. Oxford University Press.

Menkoinfo. (n.d.). JDIH KEMKOMINFO.

https://jdih.kominfo.go.id/produk_hukum/view/id/553/t/peraturan+menteri+ko munikasi +dan+informatika+nomor $+20+$ tahun $+2016+$ tanggal $+1+$ desember +2 016

Merriam-Webster. (n.d.). Pedagogy. Merriam-Webster.

https://www.merriamwebster.com/dictionary/pedagogy.

Ng, W. (2015). New Digital Technology in Education. Dalam New Digital Technology in Education: Conceptualizing Professional Learning for Educators. Springer International Publishing. https://doi.org/10.1007/978-3-319-05822-1.

O'Donald, S., Hatza, N., \& Springgay, S. (2015). The Knitivism Club. Dalam Handbook of Public Pedagogy. Routledge. https://doi.org/10.4324/9780203863688.ch36.

Paris, J. (2016). Teach From The Heart: Pedagogy as Spiritual Practice. Cascade Books.

Robertson, L., \& Scheidler-Benns, J. (2016). Critical Media Literacy as a Transformative Pedagogy. Literacy Information and Computer Education Journal, 7(1), 22472253. https://doi.org/10.20533/licej.2040.2589.2016.0297.

Ronda, D. (2016). Pemimpin dan Media: Misi Pemimpin Membawa Injil Melalui Dunia Digital. Jurnal Jaffray, 14(2), 189-198. https://doi.org/10.25278/jj71.v14i2.210.

Sailin, S. N., \& Mahmor, N. A. (2018). Improving student teachers' digital pedagogy through meaningful learning activities. Malaysian Journal of Learning and Instruction, 15(2), 143-173.

Salgues, B. (2018). Society 5.0. In Society 5.0. John Wiley \& Sons, Inc. https://doi.org/10.1002/9781119507314.

Sturdevant, J. S. (2016). The Adaptable Jesus of the Fourth Gospel. Dalam Novum Testamentum, Supplements. BRILL. https://doi.org/10.1163/9789004304239.

World Health Organization. (n.d.). Coronavirus disease 2019. https://www.who.int/emergencies/diseases/novel-coronavirus-2019. 